\title{
Dose Absorbed by Technologists in Positron Emission Tomography Procedures with FDG
}

\author{
Ademir Amaral ${ }^{1}$, Christian Itié ${ }^{2}$ and Bernard Bok ${ }^{3}$ \\ ${ }^{1}$ Grupo de Estudos em Radioproteção e Radioecologia - GERAR; Departamento de Energia Nuclear; Universidade \\ Federal de Pernambuco; Av. Prof. Luiz Freire, 1000; Cidade Universitária; ajamaral@oi.com.br; Recife - PE - \\ Brasil. ${ }^{2}$ Laboratory of External Dosimetry Studies and Researches - SDOS/DPHD/IRSN; Fontenay-aux Roses - \\ France. ${ }^{3}$ Centre Tep Paris-Nord Roger Perez; Sarcelles - France
}

\begin{abstract}
The objective of this work was to evaluate radiation doses delivered to technologists engaged in different tasks involving positron emission tomography (PET) studies with FDG (fluorodeoxyglucose). This investigation was performed in two French nuclear medicine departments, which presented significant differences in their arrangements and radiation safety conditions. Both centers administered about $300 \mathrm{MBq}$ per PET/CT study, although only one of them is a dedicated clinical PET center. Dose equivalent Hp(10) and skin dose Hp(0.07) were measured using Siemens electronic personnel dosimeters. For assessment dose absorbed by hands during drawing up of tracer and injection into the patient, a Polimaster wristwatch gamma dosimeter was employed. Absorbed dose and the time spent during each investigated task were recorded for a total of 180 whole-body PET studies. In this report, the methodology employed, the results and their radioprotection issues are presented as well as discussed.
\end{abstract}

Key words: Electronic Dosimeters, Radioprotection, Technologists, PET

\section{INTRODUCTION}

In the last two decades, positron emission tomography (PET) has emerged as clinical diagnostic technique, becoming one of the fastest growing imaging tools in modern nuclear medicine (NM). As a result, many hospitals have been interested in developing their imaging services to include PET. Thus, besides the increase in dedicated PET centers (Kearfott et al.,1992), conventional NM services have been upgraded to perform examinations with radiopharmaceuticals containing positron emitters. However, as conventional NM services are not built for the higher-energy gamma annihilation radiation of such tracers, special attention must be paid in terms of technical and administrative controls to keep radiation exposure as low as reasonably achievable (ALARA principle).

In general, radioprotection management is based on the measurement of specific dosimentric quantities. Among them, absorbed dose, i.e. the amount of energy imparted to matter by IR per unit of mass, is the fundamental physical quantity for evaluating potential biological response as a result of exposure to radiation. In SI, the unit of absorbed dose is expressed as the gray $(1 \mathrm{~Gy}=1$ ${\mathrm{J} . \mathrm{kg}^{-1}}^{-1}$ (ICRP, 1991).

To regulate the exposure of workers and the public at large, two derived dose quantities are suggested

\footnotetext{
${ }^{*}$ Author for correspondence
} 
by ICRP (ICRP, 1991): equivalent and effective doses, both of which are expressed in sievert (Sv) to distinguish them from absorbed dose in gray (Gy). Effective dose was introduced to represent the long-term risk of harm from radiation exposure, in particular the risk of radioinduced cancer (ICRP, 1991; Amaral, 2005). In addition to effective dose, other dose limits to the tissues that are most likely to receive high exposure are also recommended such as skin and hands, which are also referred to as extremities (ICRP, 1991).

For individual monitoring of an external radiation source the ambient dose equivalent at depth of 10 $\mathrm{mm}$ in soft tissue has been defined as personal dose equivalent $(H p(10))$. In order to evaluate weakly penetrating radiation, dose at $0.07 \mathrm{~mm}$ in soft tissue $(\mathrm{Hp}(0.07))$ is taken as skin dose, once $70 \mu \mathrm{m}$ is considered the skin's basal cell layer (ICRU, 1985).

Because $511 \mathrm{keV}$ positron annihilation radiation energy is much higher than the $140 \mathrm{keV}$ of conventional nuclear medicine, medical staff working in PET studies may receive a higher equivalent dose than those working only with conventional nuclear medicine tracers do. This high energy radiation, together with many variables involved in clinical routine such as the availability of shielding, administered activity and throughput of patients, have posed an impact on radiation protection considerations to the technologists working in PET procedures. This has motivated several studies for better perception of the radiation dose levels received by technologists undertaking imaging with positron-emitter tracers (Wu et al., 2000; Roberts et al., 2005; Schleipman et al., 2006; Seierstad et al., 2007).

There are several positron-emitter isotopes employed in PET studies such as Carbon-11, Nitrogen-13, Oxygen-15 and Fluorine-18, which allow many naturally occurring substances to be radiolabelled. The latter, as the radiopharmaceutical fluorodeoxyglucose $\left(\left[{ }^{18} \mathrm{~F}\right]-\right.$ FDG), is the most commonly used tracer in the clinical setting (around $90 \%$ ).

In this context, the aim of this work was to evaluate the radiation doses to technologists from some individual tasks using the [18F]-FDG for PET studies.

\section{MATERIAL AND METHODS}

\section{PET Centers}

This investigation was carried out in two nuclear medicine (NM) departments in France (A and B), presenting significant differences in their layout and radiation protection conditions, but employing only $\left[{ }^{18} \mathrm{~F}\right]-\mathrm{FDG}$ in their PET studies.

\section{Dosimeters}

For evaluating the whole-body dose $(\operatorname{Hp}(10))$ and skin dose $(\mathrm{Hp}(0.07))$, medical staff was supplied with Siemens electronic semiconductor dosimeter EPD-MK2. To assess extremity dose a Polimaster Geiger Mueller based wristwatch dosimeter PM1603 was employed, which being light, as well as small and having a dose sensitivity of $0.1 \mu \mathrm{Sv}$, was particularly suitable for this investigation (Texier et al., 2001; Sylvain and Bok, 2002).

Prior to the measurements, both dosimeters had been calibrated at $660 \mathrm{keV}$ with a ${ }^{137} \mathrm{Cs}$ source in the External Dosimetry Studies and Research Laboratory from the Institut de Radioprotection et de Sûreté Nucléaire (IRSN-France). All dosimeters checked (EPDs and wristwatch detectors) presented a satisfactory repeatability, reproducibility and sensitivity, according to recommendations of ISO 4037/3 (ISO, 1997).

\section{Individual Monitoring}

During each individual task, two semiconductor EPD dosimeters were worn by medical staff: one for measuring the daily whole-body dose and another for registering each task dose. Each dose value was obtained directly from both dosimeters and recorded at the end of each task. In the two investigated NM centers, the procedure of setting up an intravenous line has been performed prior to administering the tracer to patient.

Besides the monitoring of daily whole-body dose received by technologists working in two centers, the following tasks concerning PET procedures were investigated:

1-Drawing up of tracer;

2-Injecting the tracer;

3-Removal of intravenous lines.

The wrist dose was recorded by the wristwatch dosimeter only for the tasks 1 and 2. The procedure called "removal of intravenous lines" took into account the whole time spent by the technologist accompanying the patient through entire sequence of this task. 


\section{RESULTS}

A total number of 180 whole body PET studies were carried out in this work. The two NM centers administered activities, in $\mathrm{MBq}$, of $306 \pm 35$ (Center A) and $303 \pm 26$ (Center B) per patient of $70 \mathrm{~kg}$. Table 1 presents the measured individual dose per activity administered (nSv/MBq) for tasks carried out in Center $\mathrm{A}$, where the mean daily whole body dose absorbed by technologist was $10 \mu \mathrm{Sv}$. Table 2 shows the individual absorbed dose (nSv/MBq) for tasks performed in the Center B, where the mean daily whole body dose absorbed by technologist was $40 \mu \mathrm{Sv}$.

Table 1 - Absorbed doses per task in the Center A

\begin{tabular}{|c|c|c|c|}
\hline \multirow{2}{*}{ TASK } & \multirow{2}{*}{$\begin{array}{l}\text { Time spent } \\
(\text { min) }\end{array}$} & \multicolumn{2}{|c|}{$\begin{array}{c}\begin{array}{c}\text { Dose/injected activity } \\
(\mathrm{nSv} / \mathrm{MBq})^{*}\end{array} \\
\end{array}$} \\
\hline & & Hр(10) & Hр $(0,07)$ \\
\hline $\begin{array}{l}\text { Drawing up of tracer } \\
\text { (wrist dose) }\end{array}$ & 2.2 & $1.6 \pm 0.7$ & $1.6 \pm 0.1$ \\
\hline $\begin{array}{l}\text { Injecting the tracer } \\
\text { (wrist dose) }\end{array}$ & 1.2 & $3.0 \pm 0.9$ & $3.2 \pm 2.3$ \\
\hline $\begin{array}{l}\text { Removal of } \\
\text { intravenous lines }\end{array}$ & 2.5 & $4.7 \pm 1.5$ & $4.1 \pm 2.7$ \\
\hline
\end{tabular}

*Average \pm standard deviation

Table 2-Absorbed doses per task in the Center B

\begin{tabular}{|c|c|c|c|}
\hline \multirow{2}{*}{ TASK } & \multirow{2}{*}{$\begin{array}{l}\text { Time spent } \\
(\min )\end{array}$} & \multicolumn{2}{|c|}{$\begin{array}{c}\begin{array}{c}\text { Dose/injected activity } \\
(\mathrm{nSv} / \mathrm{MBq})\end{array} \\
\end{array}$} \\
\hline & & Hр(10) & Hр(0,07) \\
\hline $\begin{array}{l}\text { Drawing up of tracer } \\
\text { (wrist dose) }\end{array}$ & 2.6 & \multicolumn{2}{|c|}{$(20.1 \pm 4.6)$} \\
\hline $\begin{array}{l}\text { Injecting the tracer } \\
\text { (wrist dose) }\end{array}$ & 1.1 & \multicolumn{2}{|c|}{$(14.9 \pm 5.2)$} \\
\hline $\begin{array}{l}\text { Removal of } \\
\text { intravenous lines }\end{array}$ & 1.1 & $1.6 \pm 1.2$ & $2.5 \pm 2.3$ \\
\hline
\end{tabular}

*Average \pm standard deviation

\section{DISCUSSION}

It has been observed that the radiation doses to technologist working in PET studies are generally higher than for conventional nuclear medicine (Clarke et al., 1992; Harding et al., 1990, Chiesa et al., 1997; Clarke et al., 1997). However, the direct comparison of doses received by medical staff among PET services is not enough to obtain good perception of nuances in radioprotection conditions and management. For this reason, it was decided, in this work, to analyze the relationship dose per handled radioactivity (in $\mathrm{nSv} / \mathrm{MBq}$ ) instead of absorbed dose only.

From tables 1 and 2, in the case of wrist absorbed doses, only those received during ${ }^{18} \mathrm{FDG}$ drawing up presented similar results for both NM departments, namely about $20 \mathrm{nSv} / \mathrm{MBq}$. Still considering drawing up of tracer, the effective and skin doses were lower in the Center A than in B. This result was associated to the PET-dedicated workstation that is available in the center A. In the center B, the workstation used for this task was not designed to protect the technologist from $511 \mathrm{keV}$ gamma photons.

In the task concerning tracer administration to patient the wrist doses were about 7.5 and 15 $\mathrm{nSv} / \mathrm{MBq}$, respectively. This twofold difference can be explained by the use of PET Syringe Shield in Center A, but not in center B. This radioprotection condition also explains the values of $\mathrm{Hp}(10)$ and $\mathrm{Hp}(0.07)$ obtained as a result of radiopharmaceutical injection to patient.

One can observe that technologists from center B used to remove intravenous lines, on average, twice as fast as the ones from center $\mathrm{A}$, which explains the lower doses were registered for this task in that center. 
The mean daily whole-body dose to technologists working in Center A (10 $\mu \mathrm{Sv})$ was greater than for the Center B $(40 \mu \mathrm{Sv})$. The estimation for monthly whole-body dose was $194 \mu \mathrm{Sv}$ (about $0.19 \mathrm{mSv}$ ) for Center A and $325 \mu \mathrm{Sv}(\sim 0.33 \mathrm{mSv})$ for the Center B. This can firstly be related to difference in radioprotection conditions. As said before, Center A was built as a dedicated PET Center, while Center B was an adaptation from conventional NM. For example, layout, shielding of the walls and workstation of the Center A were realized to develop only PET procedures. On the other hand, Center B kept the same technical features as conventional NM project and added positron emission tasks to its routine.
Figures 1 through 3 are provided to give an idea of radioprotection conditions of the Center A. Fig. 1 shows the drawing up of $\left[{ }^{18} \mathrm{~F}\right]-\mathrm{FDG}$ in PET workstation.

Fig. 2 presents a technologist wearing the dosimeter EPD-MK2 (pointed out by the arrow) during the transportation of the shielded syringe. Although the Geiger Mueller based wristwatch dosimeter does not appear in this figure was also worn.

Fig. 3 shows the instant when the tracer is administered to patient.

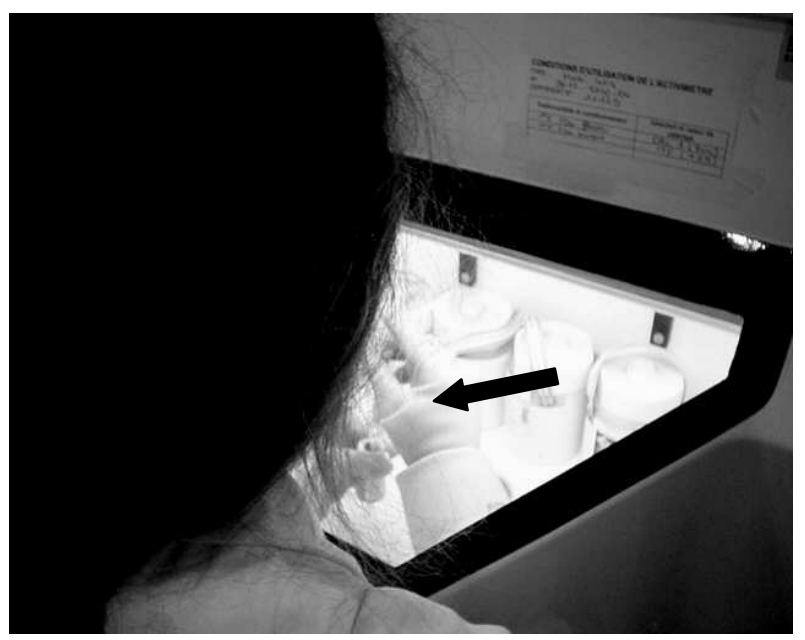

Figure 1 - Dispensing procedure in PET workstation (arrow points out drawing up of tracer)

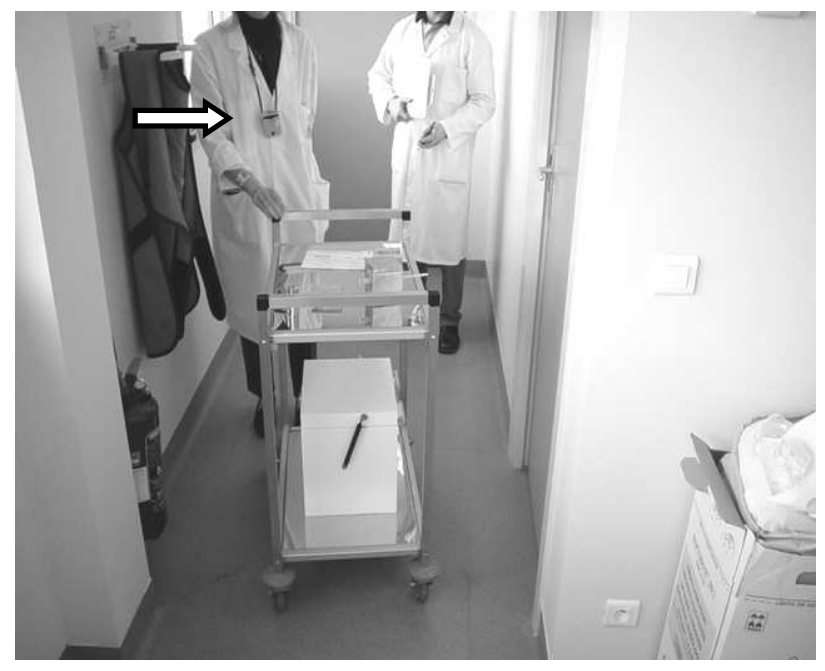

Figure 2 - Example of positioning of the electronic dosimeter during the transportation of shielded syringe 


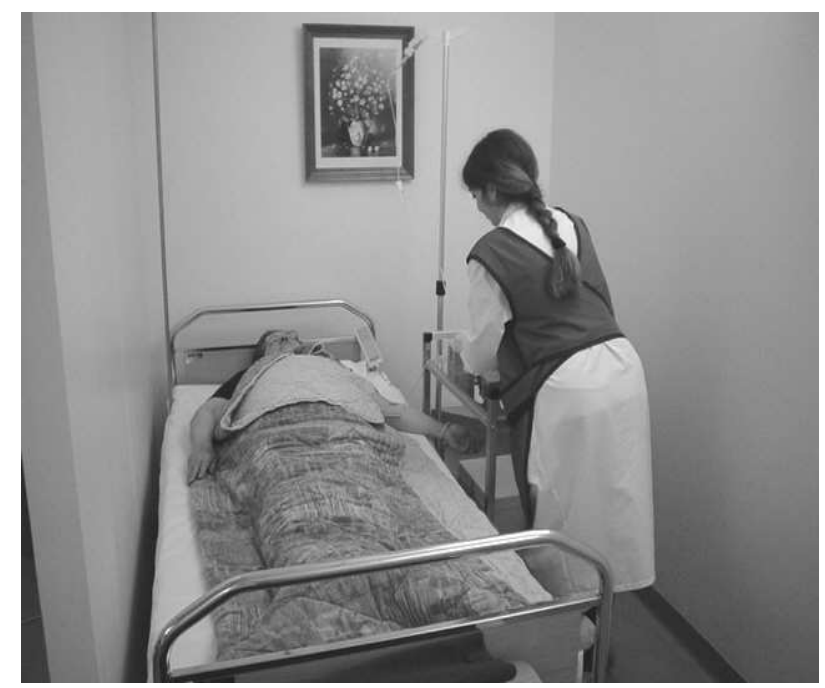

Figure 3 - Administration of tracer

These figures, taken in the Center $\mathrm{A}$, and the results presented in tables 1 and 2 do not emphasize the principal contribution to the wholebody dose absorbed by technologists is the radiation that comes from the patients.

The results presented in this work pointed out the importance of radiation protection conditions for optimization of absorbed doses delivered to technologists in such practices. Besides this, the high sensitivity of electronic dosimeters indicate these devices as being an important tool for dose management, helping to provide a better individual task distribution for workers in PET centers.

\section{ACKNOWLEDGMENTS}

The authors would like to thank: IRSN (France) for financial support; the physicians I. Delettre and J-L. Alberini, and the physicist T. Azli for their contributions during the development of this work; Mr. Thomas H. Greenhalgh for his suggestions to this manuscript.

\section{RESUMO}

O objetivo deste trabalho foi o de avaliar doses absorvidas por profissionais de saúde em diferentes tarefas relacionadas à tomografia por emissão de pósitrons com [18F]-FDG (fluordesoxiglicose). Esta pesquisa foi realizada em dois centros de medicina nuclear na França, os quais apresentavam diferenças significativas em sua organização e radioproteção. Esses centros aplicavam aproximadamente $300 \mathrm{MBq}$ por exame PET/CT, embora apenas um deles correspondesse a um serviço de medicina nuclear dedicado a exames por PET. A dose equivalente $(\mathrm{Hp}(10))$ e a dose na pele $\mathrm{Hp}(0,07)$ foram medidas usando dosímetros eletrônicos (Siemens). Para avaliação da dose nas mãos do tecnologista durante a preparação do radiofármaco e durante injeção no paciente, um dosímetro tipo relógio de pulso (Polimaster) foi empregado. A dose absorvida e o tempo empregado durante cada tarefa foram registrados para um total de 180 exames de corpo inteiro através da PET. Neste trabalho, a metodologia empregada, os resultados e suas conseqüências na dose absorvida para o profissional de saúde são apresentados e discutidos.

\section{REFERENCES}

Amaral, A. (2005), Physical and Biological Dosimetry for Risk Perception in Radioprotection, Braz Arch Biol Technol, 48, 229-234.

Chiesa, C., De Sanctis, V., Crippa F et al. (1997), Radiation dose to technicians per nuclear medicine procedure: comparison between teehnicium-99m. gallium-67. and iodine-131 radiotracers and fluorine18 fluorodeoxyglucose. Eur J Nucl Med, 24, 380-389. 
Clarke, E.A., Thomson, W.H., Notghi, A., Harding, L.K. (1992), Radiation doses from nuclear medicine patients to an imaging technologist: relation to ICRP recommendations for pregnant workers. Nucl Med Commun, 13, 795-798.

Clarke, E.A., Notghi, A., Harding, L.K. (1997), Are $\mathrm{MIBI} /$ tetrofosmin heart studies a potential radiation hazard to technologists? Nucl Med Commun, 18, 574577.

Harding, L.K., Mostafa, A.B., Thomson, W.H. (1990), Staff radiation doses associated with nuclear medicine procedures - a review of some recent measurements. Nucl Med Commun, 11, 271-277.

International Commission on Radiation Units and Measurements (1985), Determination of Dose Equivalents Resulting from External Radiation Sources, ICRU-39, Bethesda, MD.

International Commission on Radiological Protection ICRP (1991), Recommendations of the International Commission on Radiological Protection, ICRP-60, Pergamon Press, Oxford, UK.

International Organization for Standardization (1997), $\mathrm{X}$ and gamma reference radiation for calibrating dosemeters and doserate meters and for determining their response as a function of photons energy, ISO 4037-3, Genève, SW.

Kearfott, K.J., Carey, J.E., Clemenshaw, M.N., Faulkner, D.B. (1992), Radiation protection design for a clinical positron emission tomography imaging suite, Health Phys, 63, 581-589.
Roberts, F.O., Gunawardana, D.H., Pathmaraj. K., Wallace, A., Paul, L. U., Mi, T., Berlangieri, S.U., O'Keefe, G.J., Rowe, C.C., Scott, A.M. (2005), Radiation Dose to PET Technologists and Strategies to Lower Occupational Exposure. $\mathrm{J} \mathrm{Nucl} \mathrm{Med}$ Technol, 1, 44-47.

Schleipman A.R., Castronovo, F.P. Jr, Di Carli, M.F., Dorbala, S. (2006), Occupational radiation dose associated with $\mathrm{Rb}-82$ myocardial perfusion positron emission tomography imaging, J Nucl Cardiol, 13 (3), 378-384.

Seierstad, T., Stranden, E., Bjering, K., Evensen, M., Holt1, A., Michalsen, H. M., Wetteland, O. (2007), Doses to nuclear technicians in a dedicated PET/CT centre utilising 18F fluorodeoxyglucose (FDG), Radiat Prot Dosim, 123 (2), 246-249.

Sylvain, I., Bok, B. (2002), Radiation exposure in nuclear medicine: real-time measurement. Brazil Arch Biol Technol, 45, 131-134.

Texier, C., Itié, C., Serviere, H. et al. (2001) Study of the photon radiation performance of electronic personal dosimeters. Radiat Prot Dosim, 96, 245-249.

Wu, T.H., Liu, R.S., Chong, N.S., et al (2000), Evaluation of equivalent dose to work staff with Oxygen-15-watrer in positron emission tomography studies. Appl Radiat Isotop, 53, 463-468.

Received: July 31, 2007; Revised: August 08, 2007; Accepted: August 10, 2007. 